\title{
A Review of Traffic Congestion in Dar es Salaam City from the Physical Planning Perspective
}

\author{
Robert B. Kiunsi ${ }^{1}$ \\ ${ }^{1}$ Disaster Management Training Centre, Ardhi University, Dar es Salaam, Tanzania \\ Correspondence: Robert Kiunsi, Disaster Management Training Centre, Ardhi University, Dar es Salaam, P.O \\ Box 35176, Dar es Salaam, Tanzania. Tel: 255-22-275-472. E-mail: kiunsi@aru.ac.tz
}

Received: December 18, 2012 Accepted: January 20, 2013 Online Published: January 28, 2013

doi:10.5539/jsd.v6n2p94

URL: http://dx.doi.org/10.5539/jsd.v6n2p94

\begin{abstract}
Traffic congestion is one of the major problems facing Dar es Salaam City and is attributed by a number of factors including rapid population increase, inadequate and poor road infrastructure, city structure, rapid increase in number of cars and lack of physical plan to control city development. The city is already implementing a number of strategies in order to minimize traffic congestion. However, many of the strategies are focusing on improving the capacity of roads in terms of increasing number of lanes, proposing new overpasses and underpasses at the main road intersections and improving public transport. These strategies cannot fully overcome the congestion problems in Dar es Salaam on their own unless efforts are made to redistribute services and community infrastructure. The latter can be achieved through physical planning, which has the potential of influencing trip generation and travel patterns and traffic volume in specific roads. Therefore to minimize traffic congestion in the Dar es Salaam both strategies for improving road capacity, public transport and physical planning solutions ought to be applied together.
\end{abstract}

Keywords: traffic congestion, increase in cars, traffic management, road infrastructure, public transport and physical planning

\section{Introduction}

Traffic congestion is one of the key problems in Dar es Salaam, Tanzania especially during the peak hours of the mornings and evenings. It is a relatively a new phenomenon and as recent as in the middle of the 1990s congestion was not a problem at all except for a few roads in the City center. Traffic congestion is becoming worse on the yearly basis due to the increase Dar es Salaam population, number of cars, rapid physical development Central Business District and increase in social and economic activities in the City. The Government and City authorities are attempting to solve the problem by increasing the capacity of roads and improving public transport. It appears that this approach has not fully delivered the desired results of minimizing congestion. One of the contributing factors for poor performance is none implementation of strategies for controlling traffic congestion proposed in physical plans. As an example the 1979 Dar es Salaam master plan had good strategies for reducing future traffic congestion and if they were implemented traffic congestion in the City could not be as bad as it is by now. This paper attempts to show the importance of seriously taking into account physical planning as one of the key tools in reducing traffic congestion in urban areas in addition to popular strategies of increasing road capacity and improving public transport.

\section{Traffic Congestion}

According to Organization for Economic Co-operation and Development [OECD], report (2007) on managing urban traffic congestion there is no single broadly agreed definition of traffic congestion due to the fact that it is both a physical and a relative phenomenon. As a physical phenomenon traffic congestion can be defined as situation where demand for road space exceeds supply and is reflected by slower speed, longer trip times and increased motor vehicular queuing (Institute of Transport Engineers, 1989). As a relative phenomenon it can be defined as a difference between road performance and road user's expectations. Traffic congestion is a problem in many cities of the World, both in developed and developing countries and it is predicted that it will get worse in the future (Jain et al., 2012; Cambridge Systematics Inc. \& Texas Transport Institute, 2004). According to Institute of Engineers (1989) traffic congestion can be viewed from two main opposing perspectives. The first perspective is that it can be considered is an indicator of economic growth and as long as we live in urban areas 
it is here to stay with us. The second perspective is that congestion as an indicator of deterioration of urban life.

Urban traffic congestion can be contributed by a number of factors including rapid increase in urban population, economic growth, increase in employment opportunities, increase in number of cars and number of people using cars, low capacity of transport infrastructure, road layout, under investment in road infrastructure, poor traffic management, shortage of street parking, signal and equipment failure, non adherence to traffic regulations, poor urban planning or poor urban development control, rapid expansion of city boundaries, poor public transport, increased use of private cars, car accidents, special events gatherings, road works, and bad weather (Institute of Transport Engineers, 1989; Remi et al., 2009; Aderamo, 2012; Mahmud et al., 2012; Agyemang, 2009; International Association of Public Transport [UITP], 2003); Cambridge Systematics Inc. and Texas Transport Institute, 2004; LONDONASSEMBLY Transport Committee, 2004).

The impacts of traffic congestion can be categorized into four main groups of environmental, economical, health and social (Mahmud et al., 2012; Weisbrod et al., 2003; Remi et al., 2009; Levy et al., 2010). The nature, extent and severity of the impacts differ from one city to another depending among other things the city size, road capacity and road layout, spatial distribution of land uses, modes of public and private transport systems and travel patterns. The general environmental impacts due to traffic congestion include air and noise pollution and visual intrusion. Air pollution leads to increase of Greenhouse Gases (GHG) in the atmosphere thus contributing to climate change. The economic impacts are increase in fuel consumption, which leads to higher transportation costs, wastage of working time and delay in service delivery. Health impacts, which primarily occur due to extended exposure to polluted air and unnecessarily long periods spent on roads, are mental stress, tiredness, and headache. Social impacts include reduction in quality of life as reflected by reduction in personal incomes due to increased transportation costs, loss of time that could have otherwise been spent on social activities.

It is argued that traffic congestion in urban areas cannot be completely eliminated but can only be minimized to acceptable level and there is no single solution (Institute of Transport Engineers, 1989; OECD, 2007). In order to minimize traffic congestion in urban areas three main approaches may be used. These are firstly, dealing with supply side that is taking actions that lead to increase in capacity and efficiency of transportation infrastructure. Secondly, dealing with demand side that is taking actions that lead to reduction in the use of cars in urban areas. Finally, physical planning which influences land use and infrastructure distribution in urban areas. The typical supply actions for controlling traffic congestion are divided into two main areas of adding new facilities and improving the management of existing facilities. The new transportation facilities that can be added include building new roads, transit facilities, adding lanes to existing roads, constructing overpasses and underpasses at congestion intersections and building ring roads. Improved traffic management can be attained through the introduction of one way streets, turn prohibitions and reversible lanes, improving timing of the traffic signals, provision of pre trip traffic information, faster responses to traffic accidents and addressing special events and road works that cause traffic jams. Demand management can be attained by provision of high quality public transport that can reduce the use of private cars, parking restrictions, ride sharing or car pooling, ramp metering, congestion charge, promoting cycling and walking and introduction of flexible working hours.

Physical planning also known by a variety of other names including spatial planning, town planning, urban and regional planning or urban planning deals with spatial arrangement of land uses in human settlements. The main aim of physical planning is to bring orderly and sustainable development of human settlements. This is attained by developing and implementing a variety of spatial plans in urban areas, commonly known as master or structural or land use plans. The master plans do indicate the arrangements of different land uses including for example for residential, commercial, institutional, open areas, recreational and line infrastructures. The line infrastructure includes transportation facilities in terms of different types of roads, railways, water supply, energy and telecommunication systems, solid and waste management. According to Institute of Transport Engineers, (1989), and Aderamo (2012) physical planning and transportation planning are closely linked together. This is due to the fact that the way land uses are arranged will affect trip generation, travel patterns and traffic volumes which in turn will impact on the transportation facilities that are provided for accessibility to different parts of the urban areas. Therefore the travel pattern including traffic congestion within and beyond urban boundaries is greatly influenced by land uses. At the same time the transportation system can influence the land uses within and outside the urban boundaries.

\section{Dar es Salaam City}

Dar es Salaam is the commercial city and main port of Tanzania is characterized by hot and humid climate throughout the year. The average temperature of the City is $29^{\circ} \mathrm{C}$ with maximum and minimum temperatures of $35^{\circ} \mathrm{C}$ and $25^{\circ} \mathrm{C}$ respectively (UN Habitat, 2008; Nicholls, 2011). Dar es Salaam has a bimodal rainfall system 
receiving about 1000 to $1300 \mathrm{~mm}$ per annual. Topographically, the city can be divided into three main terrain units of lowlands found along Indian Ocean shores and river valleys, the middle plateau and the hilly areas found in the north and west of the city. Four main river systems of Mpiji, Msimbazi, Kizinga and Mzinga cut across the city (National Environmental Management Council [NEMC], 2009). The urban structure of the Dar es Salaam is mono-centric as it has only one Central Business District (CBD) comprising of the city center and Karikoo area. The major urban functions and activities are concentrated in the CBD and along the major arterial roads.

Overall, the City can be characterized as sprawling low rise City that is not intensively built. According to Japan International Cooperation Agency [JICA] (2008) Dar es Salaam City has a total of 1691.6 square kilometers out of this only 21.7 per cent is a built-up area. The remaining proportion that is 78.3 per cent is sparsely built or covered by either natural or semi-natural vegetation and agriculture lands mostly in peri-urban areas. The main land uses in the built-up area are residential 13.2 percent, river/water body 4 percent, industry 1.3 per cent, other land uses including government institutions 3.2 per cent.

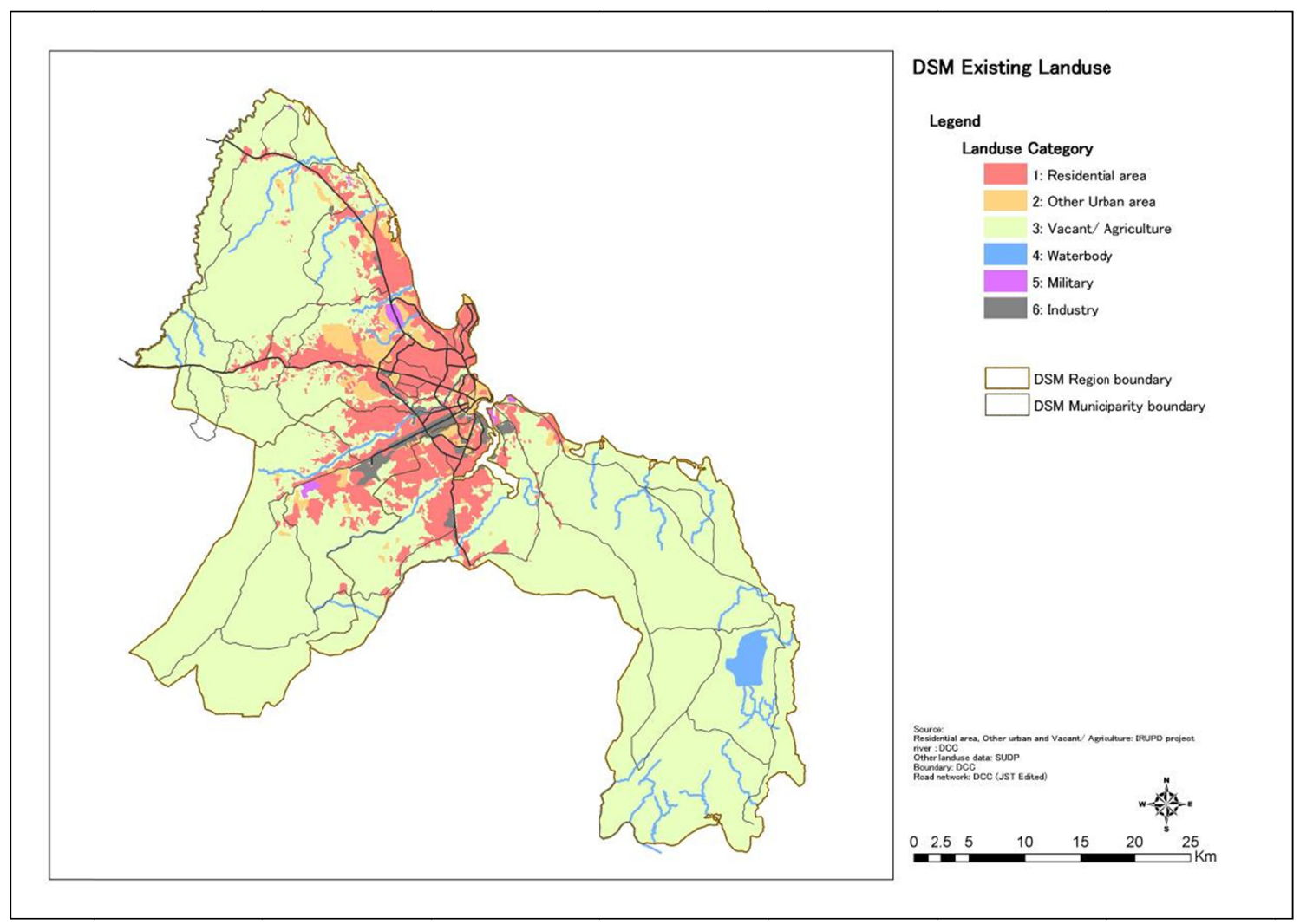

Figure 1. Main land uses in Dar es Salaam City (2007)

Source: JICA (2008).

Figure 1 shows the main land uses in Dar es Salaam (JICA, 2008). The residential houses in Dar es Salaam are dominated by single storey houses both in planned and in unplanned areas. It is estimated that currently Dar es Salaam has a population of 4 million people out of which 60 per cent are employed in the informal sector. The main income generating activities in the informal sector includes petty trading, urban agriculture, fishing, and technical jobs such as mechanics, carpentry, masonry, plumbing and tailoring (Nnkya \& Lupala, 2010; Pan-African START Secretariat, International START Secretariat, Tanzania Meteorological Agency, Ardhi University, 2011). About 65 to 70 per cent of the residents in Dar es Salaam live in unplanned settlements. Compared to population densities of many other cities, despite of its large population the city has a low population density of an average of 15 persons/ha. However, there are some areas especially those near the city center and some unplanned settlements that have 300 and 533 persons per hectare (Lupala \& Kiunsi, 2011).

Dar es Salaam City development is partly influenced by the arterial road network consisting of five main radial roads and one ring road all terminating in the Central Business District. The five radial roads are Kilwa Road, 
Nyerere Road, Morogoro Road and New and Old Bagamoyo Roads and the main ring road is the Mandela Road. The total length of roads based on 2005 data is about $1717 \mathrm{~km}$ out of which 395 or 23 per cent are paved, mostly arterial roads (JICA, 2008).

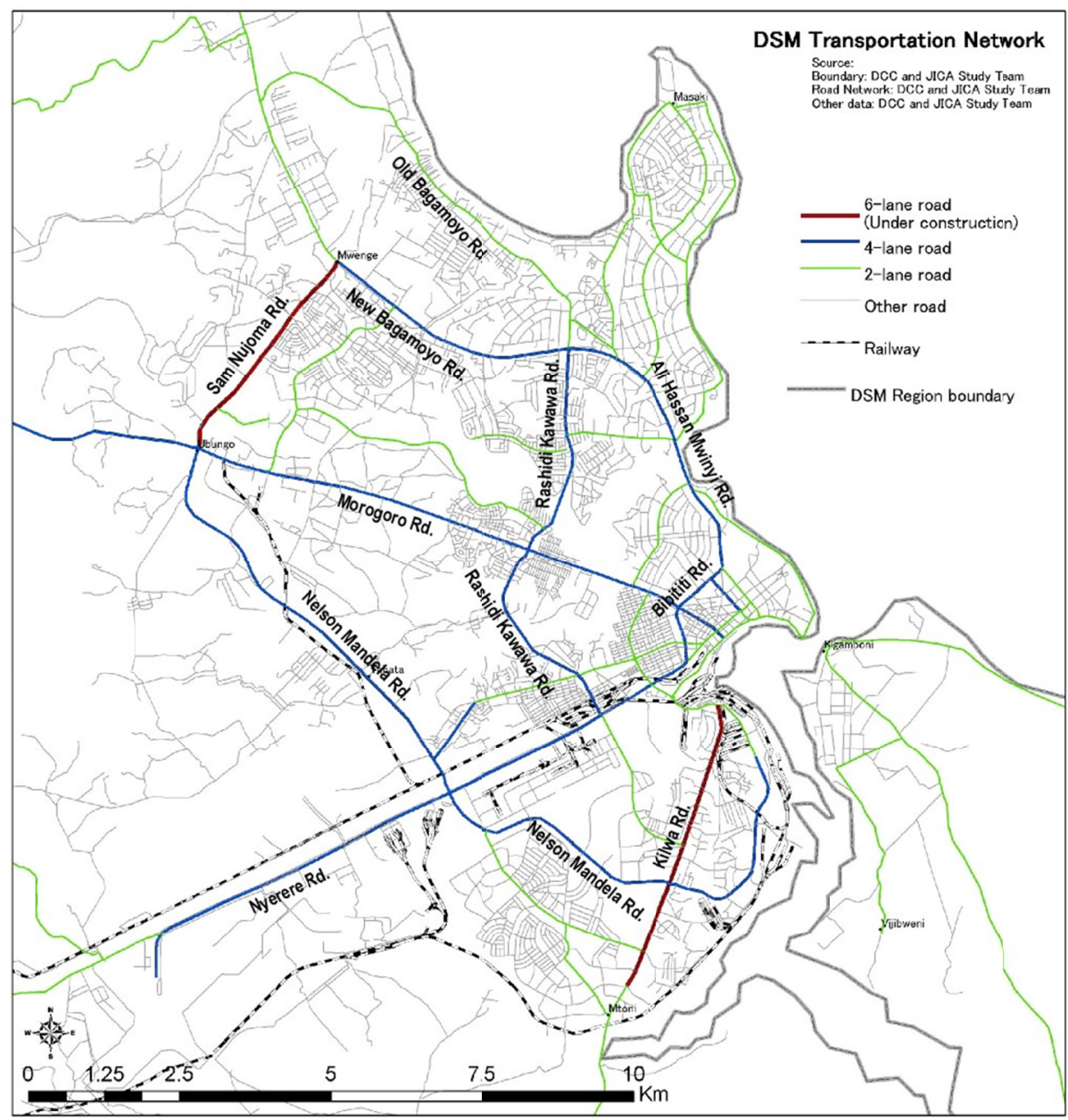

Figure 2. Roads of Dar es Salaam city

Source: JICA (2008).

Figure 2 shows the main roads in the city. The condition of roads in many of the residential and commercial areas are not paved and poorly maintained. In recent years there has been a rapid increase in importation of different types of cars in the country as reflected by Tanzania revenue Authority (TRA) registration records. Based on the Tanzania Revenue Authority records between 2003 and 2011 a total of 1010732 cars were registered by the authority. It is estimated that about 60 to 70 per cent or between 606439 to 707521000 cars are plying in Dar es Salaam roads. In addition a total of 245180 motorcycles and 7408 tricycles were registered by the TRA in 2010 and 2011 respectively. Even though there is no definite figure, most of the imported motorcycles and tricycles are plying Dar es Salaam roads (Elinaza, 2012).

\section{Methods}

This paper is primarily based on literature review, a conceptual framework paper for traffic decongestion in Dar es Salaam that was presented during the 2006 Dar es Salaam International Trade Fare and a paper on traffic congestion in Dare s Salaam that was presented during the $26^{\text {th }}$ Tanzania Institution of Engineers National Conference in 2011. The theme for the conference was on challenges in addressing traffic congestion and enhancing road safety for national development. The main literature reviewed included papers, books and newspaper reports focusing on traffic congestion in general and congestion problems in Dar es Salaam City. Using the 1997 Dar es Salaam Master Plan a critical review was made on to what extent physical planning has been used in minimizing traffic congestion in the City. 


\section{Results}

\subsection{Traffic Congestion in Dar es Salaam}

Traffic congestion is one of the major problems affecting Dar es Salaam City. A number of studies, including JICA travel speed that was conducted in 2007, have established the extent of traffic congestion in the city. As per JICA study traffic congestion is more serious in some sections of major the arterial roads such as Morogoro, Kilwa, Nyerere, Mandela, Rashidi Kawawa and Ali Hassani Mwinyi Roads mainly due to very low speed at road intersections especially during the peak hours. The congestion is more serious in the morning and evening traffic peak hours. In the morning peak hours traffic speed reduced to between 20 to $30 \mathrm{~km} / \mathrm{h}$ at a distance of 25 to 30 $\mathrm{kms}$ from the city center for most of the main roads. As one approaches the city center traffic speed is reduced to between zero to $10 \mathrm{~km} / \mathrm{h}$ within the city center and the immediate surrounding areas. In the evening peak traffic the reverse happens. Traffic speed within the city center is between 10 to $20 \mathrm{~km} / \mathrm{h}$ and decreases to between zero to $10 \mathrm{~km} / \mathrm{h}$ just outside the boundaries of the city, before picking up to speeds of more the $60 \mathrm{~km} / \mathrm{h}$ near the outskirts of the City. Traffic congestion is more critical in all major road intersections of Morogoro Road at Ubungo, Magomeni (Morogoro/Kawawa roads) Bibi Titi Mohamed and Morogoro Road junction, Nyerere Road at Tazara, Chang'ombe, Msimbazi, UN/ Kinondoni junction, Old Bagamoyo at Mwenge and Nelson Mandela Road at Tabata and Buguruni intersection. At these road intersections it is not uncommon to spend between 10 to 25 minutes before crossing.

Traffic congestion in the City has both socio-economic and environmental impacts even though no detailed studies have been conducted to establish the extent impacts. Based on time waste and extra fuel used due to congestion it is estimated that the monetary loss is about Tshs 655 billion per for private cars and commercial vehicles Katala (nd). A study conducted by confederation of Tanzania Industries showed that traffic congestion eats up about 20 per cent of business profit (Elinaza, 2010). According to Msafiri (2005), Othman (2010) and Lupala (2010) congestion is one is a major source of air pollution in the City. The main pollutants are sulfur dioxide $\left(\mathrm{SO}_{2}\right)$, nitrogen oxides (NOx), carbon monoxide (CO) suspended particulate matter (SPM), hydrocarbons ( $\mathrm{HCs}$ ) and atmospheric lead $(\mathrm{Pb})$. The concentrations of $\mathrm{SO}_{2}, \mathrm{SPM}$ and atmospheric $\mathrm{Pb}$ were found to be higher than World Health Organization (WHO) recommended standards in all sampled locations except for two sites that had no congestion in their roads.

\subsection{Factors Contributing to Traffic Congestion}

There are a number of factors contributing to traffic problems in the City including City structure, population increase, lack of overall plan to guide City development, rapid increase in numbers of motor vehicles and inadequate and poor road conditions. Each factor is briefly discussed as follows.

\subsubsection{Population Increase}

As already pointed out about 4 million people, equivalent to 10 percent of the urban population in the country are living in Dar es Salaam. The city is growing at a very fast rate as reflected by the increase its population from 0.85 million in 1978 to 1.36 in 1988, to 2.49 in 2002 and to 4 million in 2007.

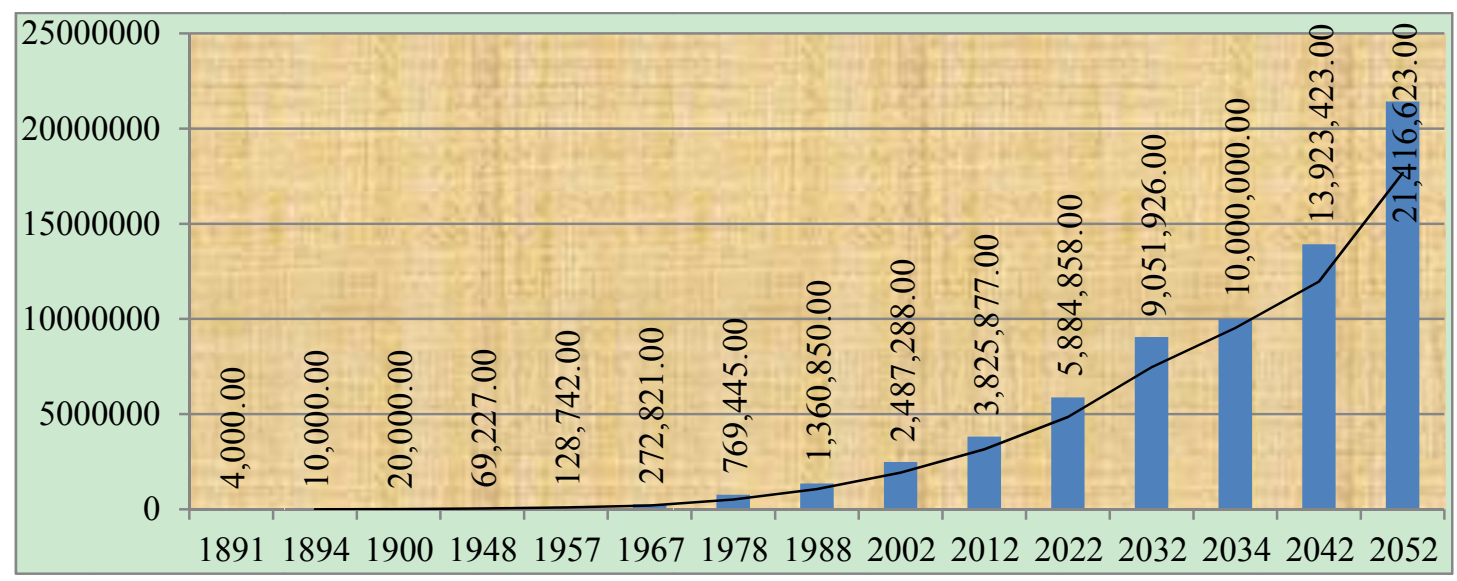

Figure 3. Trends of population growth for the Dar es Salaam city (1891-2052)

Source: Lupala and Kiunsi (2011). 
Figure 3 shows the trend of population growth in the city from 1891 to 2052 . The current growth rate is estimated to be 8 per cent per annum compared to 9.7 percent (1967-1978), 4.8 percent (1978-1988) and 4.4 percent (1988-2002). The growth rate of Dar es Salaam is one of the highest in Sub Sahara Africa. As a result of this the city cannot provide adequate services and infrastructure including transportation infrastructure to cope with population increase and therefore, contributing to traffic congestion. As a matter of fact, Dar es Salaam will become a mega city within the coming 25 years that is by 2034 . The increase in population will continue to exert pressure on road infrastructure and other social and economic services unless deliberate efforts are made to address traffic congestion in the City.

\subsubsection{Urban Sprawl}

As already indicated Dar es Salaam is low rise sprawling City. Due to resource constraints the expansive character of the City has it has been difficulty for the City authorities to provide adequate basic services including road infrastructure to new areas. The end result of urban sprawl in Dar es Salaam is the poor and inadequate provision of service infrastructure including roads. In addition to poor service provision urban sprawl forces urban dwellers to use motorized transport to travel long distances to work places and other parts of the City to obtain services and goods. The two factors of poor road infrastructure and the necessity to use motorized transport contributes to congestion in the city.

\subsubsection{Mono Centric City Structure}

As already indicated Dar es Salaam City has got only one CBD with the arterial roads originating from centre. This means that a lot of City services and institutions are located at one major point. This has led to traffic to predominantly flow from residential areas to the CBD in the mornings and vice versa in the evenings. The dominance one directional flow of traffic contributes to congestion in the mornings and evenings along the main roads and intersections (Kiunsi et al., 2006; Lupala \& Kiunsi, 2011).

\subsubsection{Lack overall Physical Plan and Development Control}

The first master plan for Dar es Salaam City, after independence, was made in 1968 and the second one in 1979 covering a period of 20 years up to 1999. Since then Dar es Salaam has not had an overall plan to guide its development. The 1979 master plan was not reviewed during the whole period of its existence apart from the City Council in 1992 introducing the Environmental Management Plan (EMP). The main objectives of EMP among other things were to increase the capacity of the city council to manage urban growth and development through participatory approaches of the communities, NGOs, central and local government and private sector. EMP was successful in identifying specific environmental issues and in developing squatter upgrading programmes but failed to deliver long term vision and comprehensive policies and guidelines for urban growth (UN-HABITAT and United Nations Environmental Programme [UNEP], 2005). Consequently, Ministry of Lands Housing and Settlement Development is now preparing a new master plan for Dar es Salaam.

The 1979 master plan Apart from not being revised was to a large extent not implemented as planned. In other words there was a very poor development control of the City during the existence of the second master plan. The concept used to develop the master plan was good and if fully implemented it could have indeed contributed to the reduction of the current traffic congestion in the city. The master plan proposed the city to be structured with six main levels of ten cell, housing cluster, neighbourhood, community and district. At each level appropriate services and community facilities could be provided.

Table 1 shows the types of facilities and services that were to be provided at each level. The plan proposed an increase of types and capacities of services as you go up the city structure. As an example at housing cluster level only a nursery school and paying ground were to be provided. While at the district level a higher order of facilities and services including commercial, office space and recreational areas were provided. The aim of the master plan was to ensure adequate distribution of facilities within the city that were within easy reach of all residents and in accordance with population thresholds as summarized below in Table 1. The master plan clearly pointed out that such urban structure would reduce the daily need to travel to the city center for common services. Unfortunately, this was not fully implemented as evidenced by many large residential areas in Dar es Salaam not having basic facilities and services. Consequently, their residents in these areas have to travel regularly to the CBD to obtain basic services and therefore contributing to traffic congestion. 
Table 1. City structure and population thresholds as proposed in 1979 master plan

\begin{tabular}{|c|c|c|}
\hline Level & Size & Services \\
\hline Ten cell unit & & \\
\hline Housing cluster & 10 ten cell units (100 plots) & Nursery school, 2 play grounds \\
\hline Neighbourhood & $\begin{array}{l}\text { Four to eighty housing } \\
\text { clusters ( } 5000 \text { people })\end{array}$ & $\begin{array}{l}\text { Primary school with associated playing grounds, } \\
\text { One local market and few small shops } \\
\text { One recreation area }\end{array}$ \\
\hline Community & $\begin{array}{l}\text { Eight neighborhoods (40 } 000 \\
\text { people) }\end{array}$ & $\begin{array}{l}\text { One major market and shopping area } \\
\text { One community hall } \\
\text { Two religious sites } \\
\text { Two major recreational areas }\end{array}$ \\
\hline District & 200000 to 300000 people & $\begin{array}{l}\text { Commercial component } \\
\text { Public and private office space } \\
\text { Wholesale and retail shopping facilities } \\
\text { Petrol service facilities } \\
\text { Apartment units } \\
\text { Institution component } \\
\text { District hospital } \\
\text { Fire protection services } \\
\text { Secondary school } \\
\text { Recreational component } \\
\text { A small exhibition area } \\
\text { A major recreational facility including playing } \\
\text { fields, athletics tracks, practice fields, } \\
\text { restaurants, offices, parking space and open } \\
\text { space }\end{array}$ \\
\hline
\end{tabular}

Ministry of Lands, Housing and Urban Development (1979).

\subsubsection{Rapid Increase in Number of Cars}

In the recent years, there has been a rapid increase in a number of imported cars in Tanzania due to a number of factors including increase in population and increase in incomes of the city dwellers, removal of restrictions on importation of cars and availability of bank loans for buying cars. The number of cars in the city has increased from 24600 in 1979 to between 606439 to 7075212011 Marshal and (Macklin Monaghan Ltd., 1979; Elinaza, 2012). The increase in the number of vehicles has compounded traffic congestion problems in the city. The situation is made worse by the increase of motorcycles and tricycles in Dar es Salaam using City roads.

\subsubsection{Inadequate Road Infrastructure and Parking Facilities}

Dar es Salaam has inadequate capacity of roads to cope with increased number of cars due to four main factors. Firstly, the spatial road coverage is low, covering only 2.5 per cent of land in Dar Salaam compared with recommended Tanzania physical planning guidelines of 15 to 20 per cent coverage (Mittal, 1976; United Republic of Tanzania [URT], 1997). Secondly, many of roads in the City are not in good condition due to lack of regular maintenance. Thirdly, all main road intersections do not have either overpass or underpass to facilitate smooth flow of traffic. Fourthly, there is limited parking space especially in the CBD. This forces some people to park on road sides thus reducing the road capacity by making the roads even much narrower. All these factors exacerbate the traffic congestion problems in the city. Finally, a number of motorists especially during morning and evening peak hours violate traffic regulations. The famous breakers of traffic regulations are the mini bus drivers and motorcyclist. 


\subsubsection{Poor Public Transport}

Public transport in the city is poor due low quality of services provided by mini buses (known as Dala dala), tricycles and motorcycles. Public service is poor due to a number of factors including limited spatial coverage provided by mini buses, lack of fixed bus time schedules, long waiting hours at the bus stops, overcrowding and at times not adhering to scheduled bus routes. Services provided by cyclists is poor because of rough riding leading to high rate of accidents. In addition poor public transport is contributed by the city being predominantly be served by mini buses instead of regular buses, which are not comfortable. Poor public transport forces a number of city dwellers who have cars to opt to use private vehicles instead of public transport.

\subsection{Efforts for Decongesting Dar es Salaam City}

The City is taking some actions to minimize congestion, which can be divided into those focusing on the supply side of traffic congestion i.e. increasing road capacity and those on the demand side i.e. reducing the number of private cars in roads. According to Guardian News paper Reporter (2010) actions taken to improve road capacity include paving more roads (Ubungo Terminal via Kigogo to roundabout of Kigogo road, Kigogo to Jangwani, Jet corner to Devis corner road, Kigogo Tabata dampo road, Old Bagamoyo road and Ununio and roads), increasing the number of lanes for the main roads (Morogoro Road, Sam Nujoma Road, Kilwa Road, New Bagamoyo Road, Kawawa Road), building new roads (Mabibo to kimara road, Mbezi Victoria via Kilungule to Kimara Korogwe road, tangi bovu to Goba Road, Ununio Road, Goba tegeta road) and improving access roads in residential areas. To further increase road capacities in the City new ring roads (Wazo hill to Mbezi Lewis and Mbezi Lewis to Ukonga) and underpass or overpass for main road intersections at ubungo and Tazara have been proposed. Actions to improve traffic management include increasing the number of traffic signals (Sam Nujoma Road, New Bagamoyo Road, Kilwa Road), deploying traffic police at the main road intersections especially during the morning and evening peak hours, introduction of one way roads mainly in the city center (independence avenue) and reversible lanes (Old and New Bagamoyo Roads). Harsh penalties especially for offenses that directly contribute to traffic congestion have been introduced to reduce traffic offences.

In order to reduce private cars in roads a number of actions have been taken. These include the improvement of public transport through the introduction of rapid transit system. The necessary infrastructure for phase one of the rapid transport system including dedicated lanes and stations along the Morogoro and Kawawa roads are now under construction. The City for the first time of its existence has also witnessed an introduction of urban trains on a limited basis from Ubungo to the City Center. The train at the moment is making only five trips per day between the City and Ubungo. The numbers of trips are expected to increase in future. The City authorities have also prohibited mini buses with capacity less than 25 percentages to transport passengers to and from the City center.

In terms physical planning, the City is currently preparing a new master plan, which addresses congestion problem. In order to minimize traffic congestion in the city the master plan has proposed four new satellite towns to be built at Bunju, Pugu Kajiungeni, Kimbiji and Kongowe (Athuman, 2010). It is hoped that the introduction of satellite towns will reconfigure land uses in the City and therefore redistributing traffic.

\section{Discussion}

Indeed traffic congestion is one of key and a growing problem in the City. The City authorities are implementing a number of strategies such as increasing the capacity of roads, improving traffic management, and improving public transport including introduction of urban train in order to reduce private cars in the roads. In addition the new master plan, still under preparation, has proposed developing of satellite towns. The satellite towns are expected to spatially redistribute centers for service provision and therefore contribute to reduction of congestions in the City. It appears that the emphasis for decongesting the City is on improving the capacity of roads and traffic management and to some extent improvement of public transport, but less emphasis physical planning. This approach may not lead to the desired results for three main reasons. Firstly, in recent years the CBD has continued to rapidly grow in terms of high rise buildings for office accommodation, hotel and commercial use. Therefore the CBD will continue to attract more and more traffic. Secondly, the rate of increase of cars is higher than the increase of road capacities. Finally, population growth rate of Dar es Salaam is high. This means that continued increase of cars will outpace the capacity of the City authorities in provision required road infrastructure. Therefore in order to minimize traffic congestion in the City, strategies for improving road capacity should strongly be supported by efforts of reconfiguring land uses through physical planning. The introduction of satellite towns as proposed in the new master plan is the move in the right direction. This however, should be supported by the actual implementation of the satellite towns. 


\section{Conclusion}

Traffic congestion is a serious and a growing problem in Dar es Salaam and has led to a number of socio-economic and environmental impacts. The nature and dynamics of traffic congestion is more or less similar as in many other cities. In Dar es Salaam congestion is contributed by a number of factors including population increase, expansion of city boundaries, economic growth, increase of number of cars, poor road infrastructure, city physical structure, lack of updated master plan and poor development control. Increasing road capacity and improvement of public transport services are the main strategies applied by the City authorities to control congestion. These strategies have not provided the desired results due a number of reasons such as a rapid increase of population and cars, rapid growth of existing CDB and non application of physical planning as a key tool for traffic congestion minimization. In order for the current solutions to work more effectively and in a sustainable way, both strategies of improving road capacities and public transport and physical planning should be applied together.

\section{References}

Aderamo, A. J. (2012). Urban transportation problems and challenges in Nigeria. A planner's view. PRIME Journals, 2(3), 197-203.

Agyemang, E. (2009). Traffic congestion: The bane of a Bus Rapid Transit System in Accra, Ghana. A master of thesis in development studies, Department of Geography Norwegian University of Science and Technology, Norway.

Athuman, R. (2010). 4 satellite town to make Dar es Salaam roomy. Retrieved 20 August, 2010, from http://dailynews.co.tz/home/?n=12573

Cambridge Systematics Inc. and Texas Transport Institute. (2004). Traffic congestion and reliability: Linking solutions to problems. Final Report. Retrieved from http://www.ops.fhwa.dot.gov/congestion_report_04/congestion_report.pdf

Elinaza, A. (2010). Dar es Salaam traffic congestion begs solutions. Daily News. Retrieved 20 October, 2010, from http://www.dailynews.co.tz/home/?n=13937

Elinaza, A. (2012). Car imports soar by 70 per cent, increase oil bill. Retrieved from http://tzexchange.blogspot.com/2012/02/car-imports-soar-by-70-per-cent.htlm

Guardian Reporter. (2010). Dar moves to reduce traffic congestion. The Guardian. Retrieved 21 September, 2010, from http://ippmedia.com/frontend/index.php?1=21221

Jackson, M. M. (2005). Roadside concentration of gaseous and particulate matter pollutants and risk assessment in Dar es Salaam, Tanzania. Environmental Monitoring and Assessment, 104, 385-407. http://dx.doi.org/10.1007/s10661-005-1680-y

Jain, V., Sharma, A., \& Subramanian, L. (2012). Road traffic congestion in the developing World. Retrieved from http://www.cs.nyu.edu/ lakshmi/traffic.pdf

JICA. (2008). Dar es Salaam Policy and System Development Master Plan. Dar es Salaam.

Katala (nd). The cost of traffic congestion and accidents to the economy in Tanzania. Unpublished report DART Agency. Retrieved from http://www.iekenya.org/download/Jumbe N.Katala

Kebede, A. S., \& Nicholls R. J. (2011). Population and Assets Exposure to Coastal Flooding in Dar es Salaam (Tanzania): Vulnerability to climate extremes. Report submitted to Global Climate Adaptation Partnership (GCAP).

Kiunsi, R., Mushi, N., \& Awadh, A. (2006). Unpublished Conception Plan for the decongestion of Dar es Salaam. An unpublished paper exhibited during the 2006 Saba Saba Trade Fair, University College of Lands and Architectural Studies.

Levy, J., Buonocore, J. J., \& von Stackelberg, K. (2010). Evaluation of the public health impacts of traffic congestion: a health risk assessment. Environmental Health, 9, 65. http://dx.doi.org/10.1186/1476-069X-9-65

LONDONASSEMBLY Transport Committee. (2004). Exploring solutions to traffic congestion in London. Retrieved from http://legacy.london.gov.uk/assembly/reports/transport/driving-change-proceedings.pdf

Lupala, J., \& Kiunsi, R. (2011). Dar es Salaam city, 50 years to come: Conceptual considerations. Unpublished working workshop paper presented during the 50 years anniversary of the University of Dar es Salaam. 
Lupala, J. (2010). Sustainable urbanization and spatial growth of the cities in the least industrialized countries; The case of Dar es Salaam City. Journal of Building and Land Development, 17.

Mahmud, K., Gope, K., \& Chowdhury, S. M. R. (2012). Possible causes and solutions of traffic jam and their impact on the economy of Dhaka City. Journal of Management and Sustainability, 2(2).

Ministry of Lands, Housing and Urban Development. (1979). Dar es Salaam Master Plan. Marshal and Macklin Monaghan Ltd, Ontario, Canada.

Mittal, S. C. (1976). Space standards for residential development for urban areas of the United Republic of Tanzania. A paper presented at Ardhi annual conference, Moshi Tanzania.

National Environmental Management Council (NEMC). (2009). Unpublished report on Dar es Salaam River Basin Management Project. A draft project concept.

Nnkya, T., \& J. Lupala. (2010). Planning Education in Tanzania: The experience of Ardhi University. The Journal of Building and Land Development, Special issue, 157-173.

OECD. (2007). Managing urban traffic congestion: Summary document. Retrieved from http://www.internationaltransportforum.org/jtrc/CongestionSummary.pdf

Othman, O. C. (2010). Roadside levels of ambient air pollutants: $\mathrm{SO}_{2}, \mathrm{NO}_{2}, \mathrm{NO}, \mathrm{CO}$ and $\mathrm{SPM}$ in Dar es Salaam City. Tanzania Journal of Natural and Applied Sciences (TaJONAS), 1(2).

Pan-African START Secretariat, International START Secretariat, Tanzania Meteorological Agency, Ardhi University. (2011). Urban Poverty and Climate Change in Dar es Salaam. A research report submitted to the World Bank.

Remi, A. J., Adegoke, A. I., \& Onyerinde, A. J. (2009). A study of the causes effects and ameliorative measures of road traffic congestion in Lagos Metropolis. European Journal of Social Sciences, 11(1).

UITP. (2003). Better urban mobility in developing countries. Retrieved from http://www.4shared.com/office/tc--7N19/Better_urban_mobility_in_devel.html

UN-HABITAT. (2008). The State of African Cities 2008: A frame work for addressing urban challenges in Africa. Nairobi.

UN-HABITAT and UNEP. (2005). The sustainable Dar es Salaam project, 1992-2003, Nairobi.

URT. (1997). The Town and Country Planning (Town Planning space standards) Regulations, Government Notice No 157, Dar es Salaam.

Weisbrod, G., Vary, D., \& Treyz, G. (2003). Measuring the economic costs of urban traffic congestion to business. Journal of the Transportation and Research Board. Published in Transportation Research Record No. 1839. 